\title{
ACUTE AND CHRONIC TOXICITY OF LOCAL ANAESTHETICS
}

\author{
B. RAYMOND FINK, M.D. *
}

The Acute Toxicity of local anaesthetics has been the subject of several excellent reviews $s^{1-3}$ and this article will mention the older work only where essential as background to the contributions of the last few years.

\section{Pharmacokinetic Considerations}

The build-up of a toxic level of local anaesthetic in the blood depends on the rate of intravascular injection, or, in the case of extravascular injection, on the rate of absorption and redistribution and, more debatably, on the rate of degradation of the offending drug. Since absorption is influenced by the regional blood flow the risk can be reduced to some extent by means of vasoconstrictors.

Blood and tissue $\mathrm{pH}$ may affect the rate of uptake into the blood and of exit into the brain. For example, since bases become ionized in an acid environment, high $\mathrm{pH}$ increases the proportion of local anaesthetic present as unionized base; that is to say, alkalaemia increases the fraction of anaesthetic present in readily diffusible form. Other things being equal, hyperventilation by an anxious patient thus predisposes the patient to a reaction. On the other hand acidosis may enhance cardiovascular toxicity.

An important buffer action occurs in the lung. ${ }^{4}$ This organ functions as a first line of defense, because it smears out an input bolus through the multiplicity of blood transit times, as happens for example at the termination of venous regional anaesthesia in the arm. In Figure 1, uptake in the lung accounts for much of the difference between pulmonary arterial and systemic arterial values, and peripheral uptake explains the still lower concentration in venous blood. It follows that the arterial drug level is more instructive than the peripheral venous level in evaluating the limits of acute toxicity. Also, interference with pulmonary absorption of the drug, as by an anatomical shunt, will tend to increase the risk of intoxication. In animal experiments autoradiograms showed that label from radioactive lidocaine injected intravenously accumulated quickly in the liver and kidneys, especially the medullary region, with the brain and heart not far behind. ${ }^{5}$ Regional blood flow presumably explains this distribution.

A local anaesthetic drug administered for regional anaesthesia in obstetrics is rapidly absorbed into the maternal blood and transmitted across the placenta. Occasionally the relatively large doses used result in high blood levels in the foetus and in neonatal depression. ${ }^{6,7}$ Absorption from the broad ligament after paracervical block is particularly speedy and is liable to produce foetal brady-

"Anaesthesia Research Center, Department of Anaesthesiology, University of Washington School of Medicine, Seattle, Washington 98195.

This investigation was supported by uspHs Research Center Grant GM 15991 and by a grant from Astra Pharmaceutical Products, Inc. 


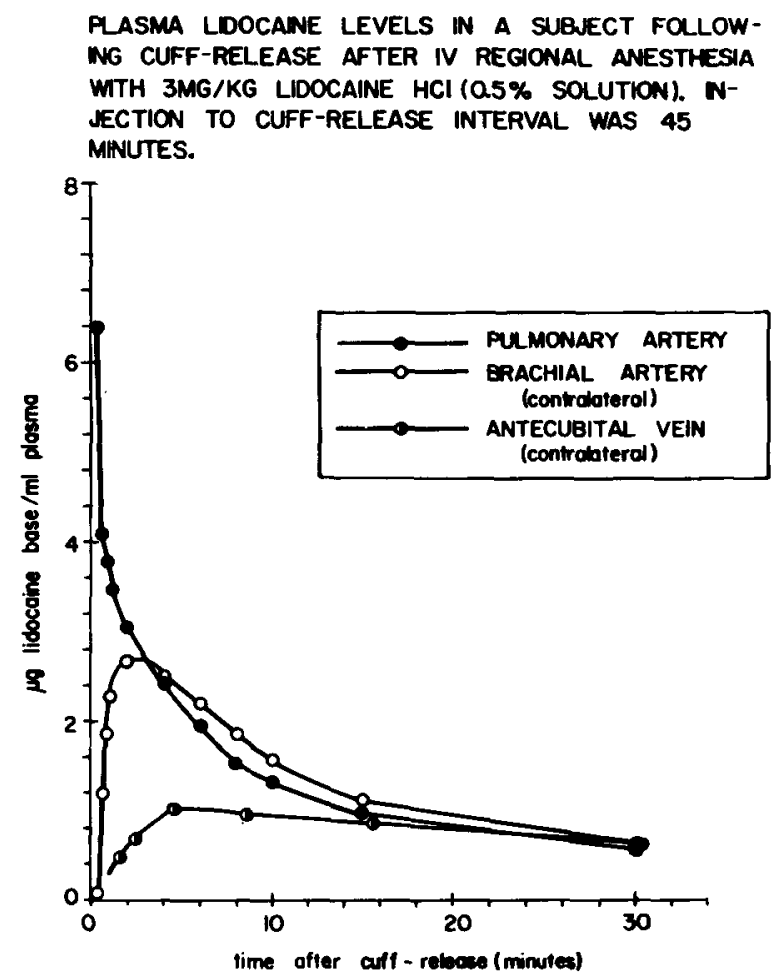

Figune 1. Plasma lidocaine levels in a subject following cuff release after intravenous regional anaesthesia with $3 \mathrm{mg} / \mathrm{kg}$ lidocaine $\mathrm{HCl}$ ( 0.5 per cent solution; $45 \mathrm{~min}$ cuff time). (G.T. Tucker and R.A. Boas, Anesthesiology 34: 538 (1971) reproduced with permission.)

cardia, ${ }^{8}$ an observation in accordance with the high myocardial levels found in rat experiments. ${ }^{9}$ Unfortunately, unlike uptake by the foetal liver, placental uptake of lidocaine is low, and does little to decrease the concentration reaching the foetal heart and brain. Accidental injection of the drug directly into the foetus has been known to occur. ${ }^{10}$

\section{Systemic Toxicity}

Much effort has been devoted to determining the acute toxicity threshold for lidocaine in man and the main evidence may be summarized here. Foldes and colleagues, ${ }^{11}$ infusing intravenous lidocaine into conscious human volunteers at the rate of $0.5 \mathrm{mg} / \mathrm{kg} / \mathrm{min}$, observed objective signs of overdosage after about 13 minutes, when an average dose of $6.4 \mathrm{mg} / \mathrm{kg}$ had been given. At this point the concentration of lidocaine in the blood was $5.3 \mu \mathrm{g} / \mathrm{ml}$. Subjective symptoms had begun after 3 minutes when $1.5 \mathrm{mg} / \mathrm{kg}$ body weight had been given. The toxic levels observed by Bromage ${ }^{12}$ were somewhat higher but he administered lidocaine intravenously to patients anaesthetized with thiopentone and nitrous oxide. In his cases (Figure 2) when $13 \mathrm{mg} / \mathrm{kg}$ had been given the venous lidocaine concentration reached a level of about $10 \mu \mathrm{g} / \mathrm{ml}$ and toxic symptoms became apparent These took the form of a falling blood pressure, the onset of apnoea and twitching 


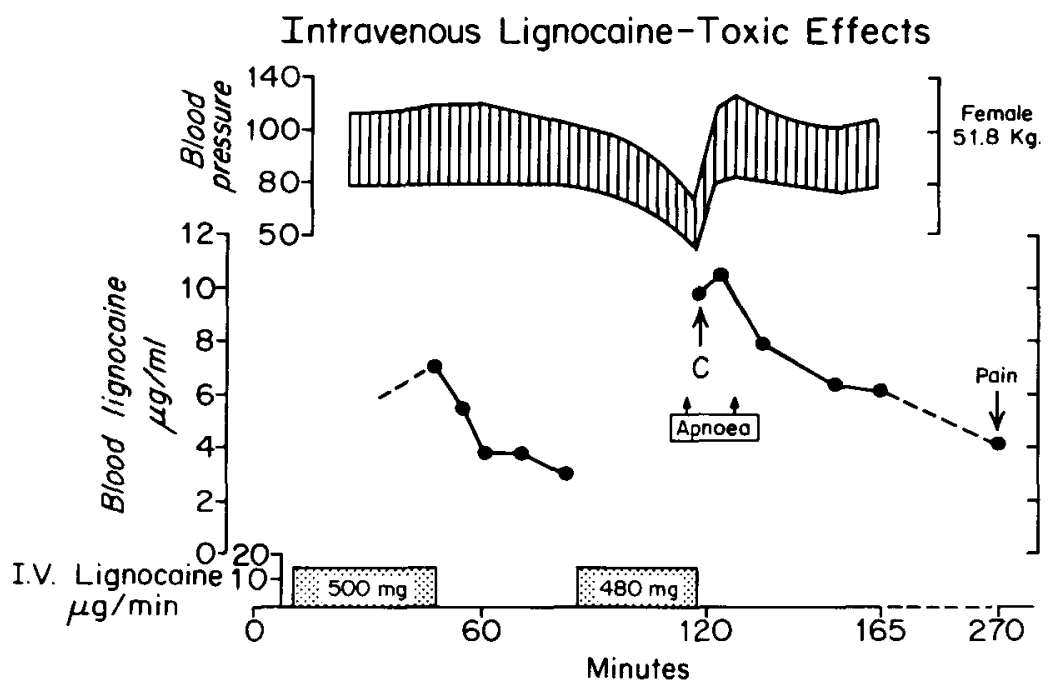

Figure 2. Concentrations of lidocaine in venous blood after intravenous infusion. $\mathrm{C}=$ convulsion. At this point, $100 \mathrm{mg}$ of thiopentone were given to abort the convulsion, followed by $10 \mathrm{mg}$ of methylamphetamine to raise the blood pressure. (P.R. Bromage and J.G. Robson, Anaesthesia 16: 461 (1971) reproduced with permissions.)

and frank convulsions. Infusion speeds below $0.3 \mathrm{mg} / \mathrm{kg} / \mathrm{min}$ did not provoke toxic effects and could be tolerated for 30 minutes.

The safe limits of intravascular injection have assumed considerable clinical importance now that local anaesthetic, particularly lidocaine, is so often deliberately administered intravenously for the control of cardiac arrhythmias. The chief threat of an overdose is not to the heart, as was once thought, but to the brain. Cardiac arrest, if it occurs, is secondary to respiratory arrest, itself an accompaniment of the epileptiform convulsion that results from the primary cerebral insult. ${ }^{11,13-17}$ The evidence indicates clearly, in both animal experiments and in man, that local anaesthetic agents administered in near-convulsant doses do not have a deleterious effect on the circulation. ${ }^{11,14,18,19}$ Jorfeldt $^{20}$ for example studied the effect of intravenous mepivacaine, lidocaine, and bupivacaine on central circulation and respiration in healthy men. Plasma levels of mepivacaine 5 to $6 \mu \mathrm{g} / \mathrm{ml}$, or bupivacaine $2.5 \mu \mathrm{g} / \mathrm{ml}$ were subconvulsant. No depressive effect of mepivacaine, bupivacaine or lidocaine on the central circulation and respiration was seen (figure 3). In fact an increase in blood pressure occurred, apparently accounted for by redistribution of blood to the central circulation in consequence of the increased peripheral venous tone. In the case of lidocaine, elevation in blood pressure may be due to a potentiation of sympathomimetic hormone action. ${ }^{21}$

In large enough doses local anaesthetics do depress the heart directly, ${ }^{22-25}$ but respiratory paralysis precedes cardiovascular collapse and is the usual cause of death. If artificial respiration is maintained, the dose producing cardiac stoppage may be several times larger than that which caused respiratory paralysis. ${ }^{26}$ This is obviously a very important consideration in assessing the risk of different agents. In Stewart's study ${ }^{27}$ the relative myocardial toxicity for the dog was found to be 

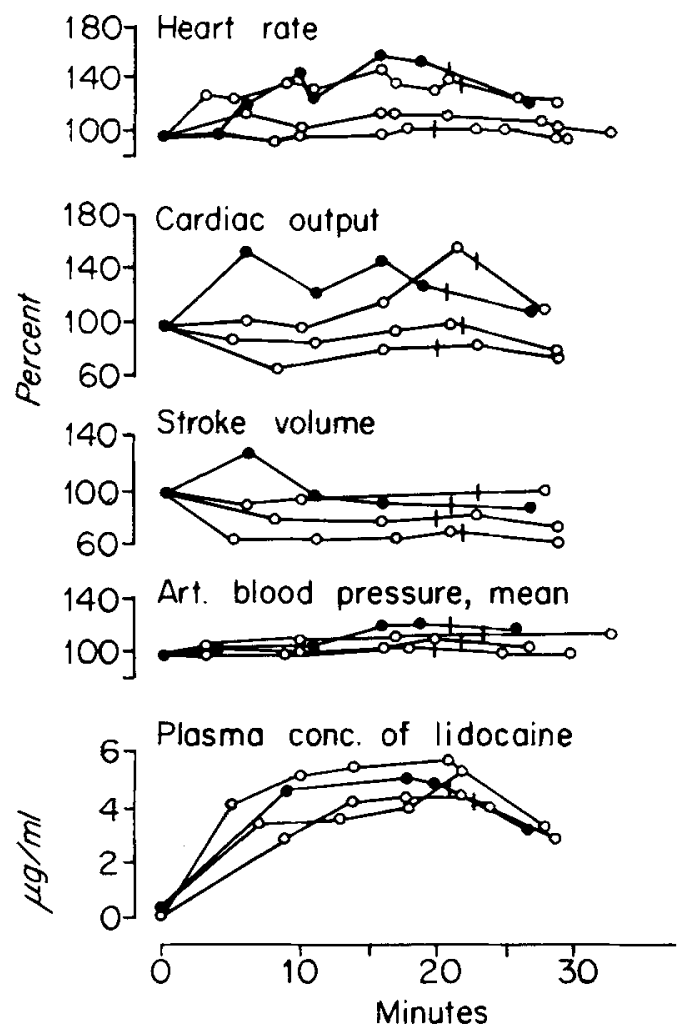

Figure 3. Haemodynamic effects of lidocaine in human subjects. A subject in whom convulsions appeared after 19 minutes of infusion is indicated by the symbol .-.

procaine 1 , chloroprocaine 2.2 , lidocaine 4.6 , hexylcaine 5.3 , cocaine 6.6 , tetracaine 8.3 ; but the animals were maintained with artificial ventilation. A direct relationship between toxic cardiac activity and local anaesthetic potency appears likely. A high degree of correlation $(\mathrm{r}=0.95)$ has been found to exist between local anaesthetic activities and the ability of the compounds to increase the refractory period of the isolated rabbit auricle. ${ }^{28}$

Clinical observation teaches that lidocaine can be given intravenously in quite large doses in the treatment or prevention of ventricular arrhythmia, without untoward effects. ${ }^{29}$ In Gianelly's hands toxic effects such as hypotension, central nervous system depression, and convulsions, were avoidable if the dose was kept below $55 \mu \mathrm{g} / \mathrm{kg} / \mathrm{min}(4 \mathrm{mg} / \mathrm{min}$ in $70 \mathrm{~kg} / \mathrm{pt}) .{ }^{30}$ However, seizures may suddenly and unexpectedly occur (Figure 3 ). The initial plasma half-life of a $1 \mathrm{mg} / \mathrm{kg}$ bolus averages 7 to 13 minutes. ${ }^{31,32}$

\section{Protective Drugs}

What can be done to protect patients from the risk of convulsions? The antidotal property of barbiturates against cocaine convulsions has been known for more than 50 years, but against other local anaesthetics the increase in the convulsant-dose $\overline{5}_{0}$ or the $\mathrm{LD}_{\overline{5} 0}$ is usually not larger than 150 per cent. ${ }^{33}$ Moreover, the 
elimination of convulsions produces only a minor or moderate decrease in toxicity in other respects. The inhalation agents, halothane, methoxyflurane and fluroxene, behave quite similarly to barbiturates. ${ }^{34}$ Low concentrations have protected rats from the obvious convulsions produced by intraperitoneal injections of procaine, lidocaine or tetracaine, but higher concentrations enhance the lethality of the latter drugs, probably by additive depression of the circulation and respiration. No specific protection is afforded by nitrous oxide or oxygen, ${ }^{35}$ although ventilation with oxygen is of course of obvious value in protecting against anoxia. However, oxygen has no preventive action against systematic reactions. $\mathrm{CO}_{2}$ makes things worse; it reduces the convulsant dose. ${ }^{17,36}$

In recent years other injectable drugs besides barbiturates have been tested for ability to prevent or abort seizures produced by local anaesthetics. The benzodiazepines, notably diazepam, deserve special mention. Diazepam has been used successfully to treat spontaneous status epilepticus in man. In cats the seizures and muscular rigidity produced by intraperitoneal or intravenous procaine and lidocaine were promptly abolished by $0.3 \mathrm{mg} / \mathrm{kg}$ of diazepam given intravenously, but this also produced very marked sedation. ${ }^{37,38}$ Antagonism by diazepam of seizures induced by local anaesthetics is probably effected by suppression of the excessive activity in the limbic system and the spread to the motor cortex.

Since cardiovascular depression is often the result of concurrent respiratory depression and subsequent hypoxaemia, the use of neuromuscular blocking agents has been advocated to terminate convulsions and to facilitate mechanical assistance of respiration. However, such drugs do not arrest the electrical seizures in the brain.

\section{Metabolism of Local Anaesthetics}

While it is generally recognized that the attainment of toxic blood levels of local anaesthetics depends primarily on the rate of absorption or intravenous administration and on the rate of redistribution in the tissues, there has been some controversy over the role of enzymatic hydrolysis in modifying the rate of development of symptoms. It has been argued that, except after intravenous administration, estertype local anaesthetics like procaine and chloroprocaine are safer than lidocaine and its congeners, because the former are capable of being rapidly hydrolyzed whereas the latter, being amides, are not hydrolized at all. ${ }^{14}$ Most probably hydrolytic breakdown of ester local anaesthetics by plasma cholinesterase not only influences their acute toxicity, but also affects the duration of the symptoms once these have begun. ${ }^{39}$ This duration is longest with the amide local anaesthetics. In the rabbit, lidocaine (diethylglycinexylidide) is oxidatively metabolized in the liver by an enzyme system localized in microsomes and requiring oxygen and reduced NADP (nicotinamide adenine dinucleotide phosphate, TPN). The principal metabolite is monoethylglycinexylidide. ${ }^{40}$ The rate of lidocaine disappearance is increased after pretreating animals with the enzyme inducer phenobarbital, ${ }^{\mathbf{4 1}, 42}$ but the increased lidocaine metabolism is by no means rapid enough to affect the initial high blood concentration which is responsible for the toxicity. The role of metabolic degradation in the liver in limiting the central nervous system toxicity of lidocaine is well brought out in recent clinical reports. In patients with hepatic insufficiency, ${ }^{43}$ or undergoing orthotopic liver transplantation, ${ }^{44}$ the rate of disap- 
pearance of lidocaine from the blood initially is hardly affected, being due to general tissue uptake; but subsequently it becomes very slow, indicating that extrahepatic degradation or elimination is proceeding at an imperceptible pace.

Metabolic breakdown products of local anaesthetics are generally less active pharmacologically than the parent compounds, with the notable exception of the products that cause methaemoglobinaemia. In the case of procaine or lidocaine the metabolites elicit detectable amounts of methaemoglobin: (1.0-1.8 per cent and 0.4-2.7 per cent of the total haemoglobin after doses of $1200 \mathrm{mg}$ and $500 \mathrm{mg}$, respectively), but not enough to produce cyanosis. ${ }^{45}$ Propitocaine ( $300 \mathrm{or} 600 \mathrm{mg}$ ) on the other hand may increase blood methaemoglobin to as much as 13.5 per cent of the total haemoglobin, or twice as much as the minimum for recognizable cyanosis. The breakdown product of prilocaine (propitocaine) incriminated in this syndrome is hydroxylated o-toluidine.

Any account of the acute toxicity of local anaesthetics must mention, however briefly, the allergic reactions to these drugs. Such reactions are rare. They may be local (dermatitis) or general, with oedema (including glottic oedema), pruritis, hypotension, asthma, nausea and vomiting, cardiovascular collapse and respiratory arrest. A patient who is sensitive to local anaesthetic may show the same sensitivity to related chemical substances, including the preservative methylparaben. ${ }^{46}$ Thus intracutaneous testing for sensitivity is best carried out with drugs free of preservatives. Cross sensitization originating from sulfa drugs and cosmetic use of p-phenylenediamine may also occur. The majority of reported cases have been of sensitivity to procaine, mostly among people like dentists or pharmacists who have frequent contacts with the drug. ${ }^{47}$ Sensitivity among dental patients is rare.

\section{Chronic Toxicity}

Up to this point we have been reviewing various aspects of the systemic toxicity of local anaesthetics. We now turn to a less dramatic and less troublesome group of reactions, those that may arise at the site of injection and which reflect the irritancy of the drug. The local anaesthetics used in medical and dental practice have been selected on the basis of relatively low irritancy, as tested in skin, conjunctiva and the like. This has been the most practical way of excluding drugs that might cause direct injury to peripheral nerves in regional block. Irritancy does not run parallel with central nervous toxicity, although local anaesthetic potency probably does. Extremely irritant compounds may have little local anaesthetic activity, and very active compounds may have only moderate irritancy.

\section{Neuropathies}

On the whole the toxicity of local anaesthetics to peripheral nerves is not recognized as a large clinical problem. The minor impact of such disorders in the literature is perhaps explained by their tendency to clear up spontaneously, but the margin of safety is not precisely known; it may be uncomfortably small and more information on the kinetics of neural uptake and efflux under clinical simulation in experimental animals is sorely needed. Even in vitro data are scarce. The uptake of ${ }^{14} \mathrm{C}$-lidocaine by toad sciatic nerve, measured by Bianchi and Strobel ${ }^{18}$ gave a half saturation time of 2.5 minutes and a wash-out time constant of about 10 minutes at 
pH 7.2. Some measurements relating to spinal anaesthesia have been made by Cohen in the dog. He performed autoradiography of the spinal cord 30 minutes after subdural injection ${ }^{49}$ and demonstrated a high concentration of drug in the posterior and lateral columns of white matter (about $1.4 \mathrm{mg} / \mathrm{g}$ of wet tissue, or 0.14 per cent), less in the anterior column and least in the gray matter.

The incidence of sensory neurological defects following spinal anaesthesia is not negligible. In a series of 10,098 spinal anaesthetics studied by Vandam and Dripp $\mathrm{s}^{50,51}$ subjective evidence of neurological disease was recorded in 71. Complaints of numbness or of numbness and tingling, or of heaviness or burning, were in some cases associated with objective signs of neurological defects in the immediate postoperative period. The defects lasted for a few days to more than six months without progression in severity or extent and were confined almost entirely to the lumbar and sacral areas of the body, in the region corresponding to the region of the spinal cord or of subarachnoid space where the concentration of anaesthetic in contact with the neural tissues had been greatest. Numbness was not found to be associated with the usual sequelae lumbar puncture, headache and ocular and auditory abnormalities.

In other neuropathies developing after the administration of local anaesthesia, ${ }^{52}$ the course has been similar to that found following spinal anaesthesia; however it is not possible to distinguish between the trauma of injection and the presence of the local anaesthetic as a cause of the symptoms. In two series of brachial plexus nerve block totaling more than 700 patients, persistent neurological symptoms occurred in about 5 per cent. ${ }^{53}$

There is a limited class of patients in whom prolonged interruption of regional sensation is desired and can be attempted by blocking a mixed motor and sensory nerve. Since interruption by nerve section leads to a characteristic atrophy of the deprived muscles, it is reassuring to know that paralysis produced by means of long-term conduction block of motor nerve is fully reversible. This has been demonstrated by Robert and Oester ${ }^{54}$ by leaving a lidocaine-silicone polymer implant in contact with the sciatic nerve of rabbits for more than one week. Supersensitivity to acetylcholine and fibrillary potentials did not appear, and recovery from paralysis occurred within a few hours of removal of the implant. One may note that in these as in so many other experiments the exact concentration of the drug at the site of action is not known, except that it will usually be lower than the concentration administered.

Truant and Takman ${ }^{55}$ state that irreversible block of the bioelectrical events in isolated nerve trunks can be demonstrated after a 30-minute exposure to $10 \mathrm{mM}$ tetracaine or dibucaine, $40 \mathrm{mM}$ lidocaine, or $80 \mathrm{mM}$ procaine (roughly $0.25,1$ and 2 grams per cent respectively). Given more time the effect can be obtained with lower concentrations. ${ }^{56}$

On the whole the neurotoxicity of local anaesthetics in experimental preparations has received surprisingly little study. One must go back to $1930^{57}$ for the observation that novocaine borate 0.5-2 per cent produces concentration-dependent oxygen uptake by the rabbit vagus nerve, but this result seems to have been submerged in the literature by negative results with brain slices ${ }^{58}$ and sympathetic ganglia. ${ }^{59}$ At present the idea prevails that the metabolism of neural tissue is not significantly 

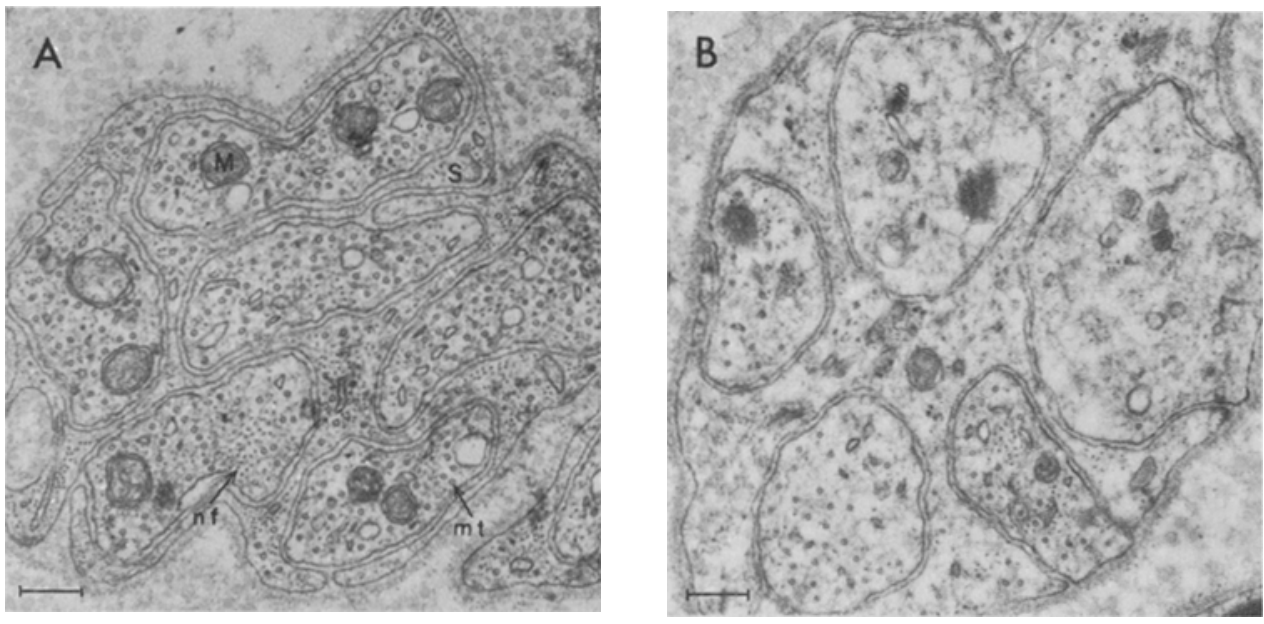

FIGURE 4. Electron micrographs from a pair of rabbit vagus nerves incubated $1.5 \mathrm{~h}$. in culture medium. A. control, B. 0.4 per cent lidocaine $\mathrm{HCl}$ added - nf, neurofilaments; nt, nicrotubules; M. mitochondrion; S. Schwann cell. Note loss of microtubules and swelling of Schwann cell and axons in B ( micrographs by courtesy of Dr. Margaret R. Byers) ${ }^{65}$

affected by the clinical use of local anaesthetics. Preliminary work by P. Berges in the author's laboratory indicates that this idea may have to be revised. The oxygen uptake by the sciatic nerve of the rabbit completely ceases in vitro in the presence of 0.7 per cent lidocaine.

\section{Toxicity to Skeletal Muscle}

As mentioned above, we now know that electrical conduction in its supplying nerve is not essential to the health of a muscle, since long term paralysis by local anaesthetic nerve block is harmless. Paralysis produced by application of the local anaesthetic directly to the muscle is quite another matter. This was discovered by Brun, ${ }^{60}$ who was primarily interested in assessing the effects of local anaesthetics on tensile strength of healing wounds. He found that $0.5-2$ per cent procaine, mepivacaine, or lidocaine, injected at the surface of a muscle in rabbits, caused subcutaneous inflammatory reactions and a significant atrophy of the muscle fibers. Concentrations of 0.25 per cent to 2 per cent were effective in this respect. Equally strong subcutaneous inflammatory reactions have lately been observed in rats. With bupivacaine, necrosis of the muscle fibers occurs within 15 minutes of the injection and is followed by an inflammatory reaction and remarkably rapid regeneration, ${ }^{61,62}$ complete in about one week.

\section{Protein Metabolism}

Some evidence tending to implicate protein synthesis in the recovery from local anaesthetic conduction blockade has been reported, ${ }^{63}$ in the shape of delayed return of motor function after pretreatment with inhibitors of protein synthesis inhibitor (cycloheximide, puromycin, chloramphenicol). An attempt to repeat this observation in the reviewer's laboratory has not been successful. On the other hand recent work has demonstrated that protein transport in peripheral nerves can quite 
easily be inhibited by local anaesthetic and that at the same time the axonal microtubules disappear from the axoplasm (Figure 4) ${ }^{64}$ At least this is what happens in isolated nerves. The concentrations producing such effects are lower than concentrations used for clinical block, but the significance of the phenomenon in iatrogenic nerve injury remains to be determined.

The question of the toxicity of local anaesthetic for human ciliated respiratory epithelium is of some practical importance, since local anaesthetics are freely used to produce topical anaesthesia of the airway. Tested on cell cultures, clinically useful concentrations are not harmful although the margin of safety is smaller with tetracaine and dibucaine than with procaine, lidocaine and chloroprocaine. ${ }^{6}$

\section{RÉSUMÉ}

Les blocages nerveux avec des anesthésiques locaux sont des gestes très fréquents, particulièrement en chirurgie dentaire. Si l'on en juge par le petit nombre de rapports qui traitent de complications, il faut conclure que le blocage nerveux est un traitement de toute sécurité. Le faible écho de ces désordres dans la littérature s'explique probablement par la tendance de ces ennuis à se dissiper spontanément.

On peut présumer, qu'à la suite de blocages nerveux, il s'ensuive des désordres sensoriels prolongés et, cela, peut-être plus fréquemment qu'on ne le croit ; toutefois, s'il survient des séquelles, elles sont rarement graves et ne produisent pas d'incapacité permanente. Dans deux séries de blocages du plexus brachial faisant un total de 700 malades, il est survenu des symptômes neurologiques persistants dans environ 5 pour cent des cas. En somme, la neurotoxicité des anesthésiques locaux ne constitue pas un problème clinique d'envergure, mais la marge de sécurité peut être dangeureusement étroite, et il s'impose d'avoir des données plus précises sur l'absorption et l'élimination chez les animaux d'expérience pour simuler le travail clinique. Bianchi et Strobel ont mesuré l'absorption de la procaine C14 et de la lidocaine C14 par le nerf sciatique in vitro. Le demi-temps de saturation pour la lidocaine a été de $2.5 \mathrm{~min}$. et le temps régulier d'élimination a été de $10.55 \pm 0.72 \mathrm{~min}$. à un $\mathrm{pH}$ de 7.2 .

L'autoradiographie de la moelle épinière de chiens après rachianesthésie montre que les colonnes postérieures et latérales sont plus marquées que la substance grise. L'étude des effets des anesthésiques locaux sur la fine structure du nerf n'a pas été faite par d'autres laboratoires et les rapports concernant les effets des anesthésiques locaux sur le transport dans les nerfs demeurent bien fragmentaires.

Le métabolisme des médicaments n'est probablement pas un facteur dans les réactions toxiques : les métabolites résultant du métabolisme des anesthésiques locaux d'usage courant sont probablement moins actifs, pharmocologiquement, que les produits mères.

L'acidose métabolique et les troubles électrolytiques peuvent influencer la toxicité de l'anesthésique local. La dépression cardiaque et l'excitation centrale sont plus marquées en présence d'acidose ( $\mathrm{pH} 7.0 \mathrm{chez}$ les chiens). En ce qui concerne l'intéraction des médicaments, l'intéraction avec les barbituriques est d'une importance particulière. Si l'on emploie les barbituriques pour calmer l'excitation du 
système nerveux central, l'action inotropique négative du barbiturique peut s'ajouter à celle de la lidocaine. Le diazepam, comme substitut du barbiturique, est encore à l'étude en ce moment. Il est extrêmement rare de rencontrer une vraie allergie aux anesthésiques locaux.

\section{REFERENCES}

1. Löfström, B. Aspects of the pharmacology of local anaesthetic agents. Brit. J. Anaesth. 42: $194(1970)$.

2. LudUena, F.P. International encyclopedia of pharmacology and therapeutics. Local Anesthetics. Vol. I. Edited by P. Lechat. New York, Pergamon Press, 1971. p. 319.

3. Covino, B.G. Local anesthesia. New Engl. J. Med. 286: 975 (1972).

4. TuCker, G.T. \& BoAs, R.A. Pharmacokinetic aspects of intravenous regional anesthesia. Anesthesiology 34:538 (1971).

5. Katz, J., Gershwin, M.E., \& Hood, N.L. The distribution of ${ }^{14}$ C-labelled lidocaine in the rat using whole-body autoradiography. Arch. internat. Pharmacodyn. 175: 339 (1968).

6. Monishima, H.L., Daniel, S.S., Finster, M., Poppers, P.J., \& James, L.S. Transmission of mepivacaine hydrochloride (Carbocaine) across human placenta. Anesthesiology 27: 147 (1.966).

7. Shrider, S.M. \& WAY, E.L. The kinetics of transfer of lidocaine (Xylocaine ${ }^{\circledR}$ ) across the human placenta. Anesthesiology 29: 944 (1968a).

8. Gorpon, H.R. Fetal bradycardia after paracervical block. New Engl. J. Med. 279: 910 (1968).

9. Finster, M., Morishima, H.O., Boyes, R.N., \& Covino, B.G. The placental transfer of lidocaine and its uptake by fetal tissues. Anesthesiology $36: 159$ (1972).

10. Sinclatr, J.C., Fox, H.A., Lentz, J.F., Fuld, G.L., \& Murphy, J. Intoxication of fetus by a local anesthetic, a newly recognized complication of maternal caudal anesthesia. New Engl. J. Med. 273: 1173 (1965).

11. Foldes, F.F., Molloy, R., McNall, P.G,, \& Koukal, L.R, Comparison of toxicity of intravenously given local anesthetic agents in man. JAMA 172: 1493 (1960).

12. Bromage, P.R. \& Robson, J.G. Concentrations of lignocaine in the blood after intravenous, intramuscular epidural and endotracheal administration. Anaesthesia 16: 461 (1961).

13. Mark, L.D., Brand, L., \& Goldensonn, E.S.L. Recovery after procaine-induced seizures in dogs. Electroenceph. clin. Neurophysiol. 16: 280 (1964).

14. Foldes, F.F., Davison, G.M., DoncalF, D., \& Kuwabara, S. The intravenous toxicity of local anesthetics agents in man. Clin. Pharmacol. Ther. 6: 328 (1965).

15. Usubiaga, J.E., Wikinski, J., Ferrero, R., Usubiaga, L.E., \& Wikinski, R. Local anesthetic-induced convulsions in man: an electroencephalographic study. Anesth. Analg. 45:611 (1966).

16. Wagman, I.J. \& DE Jong, R.H. Relation between $\mathrm{PCO}_{2}$ and electrical seizure activity induced by lidocaine. Fed. Proc. 23: 348 (1964).

17. Englesson, S., Paymaster, N.J., \& Hill, T.R. Electrical seizure activity produced by Xylocaine ${ }^{(8)}$ and Citanest ${ }^{\circledR}$. Acta anaesth. scand. Suppl. 16:47 (1965).

18. KaO, F.F. \& JALAR, U.H. The central action of lignocaine and its effect on cardiac output. Brit. J. Pharmacol. 14: 522 (1959).

19. Binnion, P.F. Toxic effects of lignocaine on the circulation. Brit. med. J. 2: 470 (1968).

20. Jorfeldt, L., Löfstrim, B., Pernow, B., Persson, B., Wahren, J., \& Widran, B. The effect of local anaesthetics on the central circulation and respiration in man and dog. Acta anaesth. Scand. 12: 153 (1968).

21. D'Amato, H.E. \& Truant, A.P. Potentiation of epinephrine and norepinephrine blood pressure responses by local anesthetic agents. Arch internat. Pharmacodyn. 101: 113 (1955).

22. Steinhaus, J.E. A comparative study of the experimental toxicity of local anesthetic agents. Anesthesiology 13:577 (1952).

23. Steinhaus, J.E. Local anesthetic toxicity: a pharmacological re-evaluation. Anesthesiology 18: 275 (1957).

24. Steinhaus, J.E., Stewart, D.M., Rogers, W.P., Mahaffey, J.E., Witherspoon, S., \& Woods, E.F. Effect of local anesthetics on the cardiovascular system of the dog. Anesthesiology 24: 620 (1963). 
25. Austin, W.G. \& Monan, J.M. Cardiac and peripheral vascular effects of lidocaine and procainamide. Amer. J. Cardiol. 16: 701 (1965).

26. DaOs, F.G., Lopez, L., \& VIRTUE, R.W. Local anesthetic toxicity modified by oxygen and by combination of agents. Anesthesiology 23: 755 (1962).

27. Stewart, D.M., Rogers, W.P., Mahaffey, J.E., Witherspoon, S., \& Woods, E.F. Effect of local anesthetics on the cardiovascular system of the dog. Anesthesiology 24:620 (1963).

28. Luduena, F.P. \& Hoppe, J.O. Corneal anesthetic activity and toxicity of some alkoxy analogs of thiocaine and related compounds. J. Amer. Pharm. Ass. Sc. Ed., 44: 393 ( 1955 ).

29. Lown, B., Vassaux, C., Hood, W.B., Fakhro, A.M., Kaplinsky, E., \& Roberge, G. Unsolved problems in coronary care. Am. J. Cardiol. 20: 494 (1967).

30. Gianeliy, R., von der Groeben, J.O., Spivack, A.P., \& Harrison, D.C. Effect of lidocaine on ventricular arrhythmias in patients with coronary heart disease. New Engl. J. Med. 277: 1215 (1967).

31. KLEIN, S.W., Sutherland, R.I.L., \& Morch, J.E. Hemodynamic effects of intravenous lidocaine in man. Canad. Med. Ass. J. 99: 472 (1968).

32. Rowland, M., Thomson, P.D., Guichard, A., \& Melmon, K.L. Disposition kinetics of lidocaine in normal subjects. Ann. N.Y. Acad. Sci. 179: 383 (1971).

33. ZIPF, H.F. Lokalanästhetica im Lichte ihrer allgemein Wirkungen. Arzneim. Forsch. 7: 529 (1957).

34. Staniweski, J.A. \& Aldprete, J.A. The effects of inhalation anaesthetic agents on convulsant (LD-50) doses of local anaesthetics in the rat. Can. Anaes. Soc. J. 17: 602 (1970).

35. Munson, E.S., Pugno, P.A., \& Wagman, I.H. Does oxygen protect against local anesthetic toxicity? Anesth. Anal. 51: 422 (1972).

36. De Jong, R.H., Wagman, I.H., \& Prince, D.A. Effect of carbon dioxide on the cortical seizure threshold to lidocaine. Exp. Neurol. 17: 221 ( 1967).

37. Feinstein, M.B., Lenard, W., \& Matrias, J. The antagonism of local anesthetic induced convulsions by the benzodiazepine derivative diazepam. Arch. inter. Pharmacodyn. Ther. 187: 144 (1970).

38. De Jong, R.H. \& Heavner, J.E. Diazepam prevents local anesthetic seizures. Anesthesiology $34: 523(1971)$.

39. Cahill, J.F., Aldous, J.G., \& Wenning, A.S. The relation between acute toxicity and critical rate of disposal of several local anesthetics. Can. J. Physiol. Pharmacol. 43: 343 (1965).

40. Hollunger, G. On the metabolism of lidocaine. I. The properties of the enzyme system responsible for the oxidative metabolism of lidocaine. Acta pharmacol. toxicol. 17: 356 (1960).

41. Heinonen, J. Influence of some drugs on toxicity and rate of metabolism of lidocaine and mepivacaine. Ann. Med. Exp. Biol. Fenn. 44: Suppl. 3 ( 1966 ).

42. DiFAzio, C.A. \& Brown, R.E. Lidocaine metabolism in normal and phenobarbital-pretreated dogs. Anesthesiology 36: 238 (1972).

43. Selden, R. \& Sasahara, A.A. Central nervous system toxicity induced by lidocaine. JAMA 202: 142 (1967).

44. Aldrete, J.A., Homatas, J., Boyes, R.N., \& Starzl, T.E. Effects of hepatectomy on the disappearance rate of lidocaine from blood in man and dog. Anes. Anal. 49:687 (1970).

45. HJELM, M. \& HolmDAHL, M.H. Methaemoglobinaemia following lignocaine. Lancet 1 : $53(1965)$.

46. Aldpete, J.A. \& Johnson, D.A. Allergy to local anesthetics. JAMA 207: 356 (1969).

47. Nevin, M.I. \& Epstern, E. Survey of sensitivity of skin to primacaine hydrochloride. Curr. Res. Anesth. 36: 42 (1957).

48. Bianchi, C.P. \& Strobel, G.E. Modes of action of local anesthetics in nerve and muscle in relation to their uptake and distribution. Trans. N.Y. Acad. Sci. Ser. 230: 1082 (1968).

49. Cohen, E.N. Distribution of local anesthetic agents in the neuraxis of the dog. Anesthesiology 29: 1002 (1968).

50. Vandam, L.D. \& Dripps, R.D. A long-term follow-up of 10,098 spinal anesthetics. II. Incidence and analysis of minor sensory neurological defects. Surgery 38: 463 (1955).

51. VANDAM, L.D. \& DRIPPS, R.D. Long-term follow-up of patients who received 10,098 spinal anesthetics. IV. Neurological disease incident to traumatic lumbar puncture during spinal anesthesia. JAMA 172: 1483 (1960).

52. Goldstein, N.P., Grbirisco, J.A., \& Rushton, J.G. Etiology of trigeminal neuropathy: a study of etiology with emphasis on dental causes. JAMA 184: 458 (1963). 
53. Woolley, E.J. \& VANDAM, L.D. Neurological sequelae of brachial plexus nerve block. Ann. Surg. 149: 53 (1959).

54. Robert, E.D. \& OEster, Y.T. Nerve impulses and trophic effect. Arch. Neurol, 22: 57 (1970).

55. Truant, A.P. \& Takman, B. Local anesthetics. Drill's Pharmacology in Medicine. Third Edition. Edited by J.R. Di Palma. New York, McGraw-Hill, 1965, pp. 133.

56. Truant, A.P. \& Takman, B. Differential physical-chemical and neuropharmacologic properties of local anesthetic agents. Anes. Anal. 38: 478 (1959).

57. SHERIF, M.A.F. The effect of certain drugs on the oxidation processes of mammalian nerve tissue. J. Pharmacol. Exp. Ther. 38: 11 (1930).

58. Geddes, I.C. \& QUASTEL, J.H. Effects of local anaesthetics on respiration of rat brain cortex in vitro. Anesthesiology 17: 666 (1956).

59. Larrabee, M.G. \& Bronk, D.W., \& Posternak, J.M. Effects of chemical agents on metabolism and function synapses and fibers in sympathetic ganglia. Fed. Proc. 6: 148 (1947).

60. Brun, A. Effect of procaine, carbocaine, and xylocaine on cutaneous muscle in rabbits and mice. Acta anaesth. Scandinav. 3: 59 (1959).

61. Libelius, R., Sonesson, B., Stamenovic, B.A., \& Thesleff, S. Denervation-like changes in skeletal muscle after treatment with a local anaesthetic (Marcaine $\left.{ }^{\circledR}\right)$. J. Anat. 106: 297 (1970).

62. Benort, P.W. \& Belt, W.D. Some effects of local anesthetic agents on skeletal muscle. Exp. Neurol. 34: 264 (1972).

63. KNAPP, D.E. \& MEJIA, S. Role of protein synthesis in recovery from local anestheticinduced conduction blockade. Anes. Anal. 48: 189 (1969).

64. Fink, B.R., Kennedy, R.D., Hendrickson, A.E., \& Middaugh, M.E. Lidocaine inhibition of rapid axonal transport. Anesthesiology $36: 422$ (1972).

65. Byers, M.R., Hendrickson, A.E., Fink, B.R., Kennedy, R.D., \& Mrodaugh, M.E. Effects of lidocaine on axonal morphology, microtubules, and rapid transport in rabbit vagus nerve in vitro. J. Neurobiol. (in press).

66. Conssen, G. \& Allen, C.R. Cultured human respiratory epithelium: Its use in the comparison of the cytotoxic properties of local anesthetics. Anesthesiology 21: 237 (1960). 